\title{
Journal of the History of Biology
}

\author{
Editor: EVERETT MENDELSOHN \\ Harvard University

\section{Associate Editor: SHIRLEY A. ROE Harvard University}

The Journal of the History of Biology is devoted to the history of the biological sciences, with additional interest and concern in philosophical and social issues confronting biology. While all historical epochs are welcome, particular attention has been paid in recent years to developments during the nineteenth and twentieth centuries. The Journal is now published three times each year. It serves the working biologist who needs a full understanding of the historical and philosophical bases of the field as well as serving the historian of science interested in following developments in the biological sciences.

\section{Some Recent Articles}

Viktor Hamburger: Hilde Mangold: Co-Discoverer of the Organizer. L.S. Jacyna: The Romantic Programme and the Reception of Cell Theory in Britain. P.F. Stevens: Haüy and A.P. Candolle: Crystallography, Botanical Systematics, and Comparative Morphology, 17801840. Michael Boylan: The Galenic and Hippocratic Challenges to Aristotle's Conception.Theory. L. T. Evans: Darwin's Use of the Analogy between Artificial and Natural Selection.

\section{Subscription Information}

1985, Volume 18 (3 issues)

ISSN 0022-5010

Institutional rate: Dfl. 190,-/US\$72.00 per volume incl. postage/ handling

Private rate: DfI. 72,-/US\$ 26.00 per volume incl. postage/handling Private subscriptions should be sent direct to the publishers.

\section{REIDEL PUBLISHING COMPANY}




\section{CLIO MEDICA}

Acta Academiae Internationalis

Historiae Medicinae

The Subscriptionprice for 1984

Hfl. $120,-$

Private individuals

Hfl. $60,-$

Contents 1984/1-2:

Alex Sakula, Doctor Nehemiah Grew (1641-1712) and the Epsom Salts; Donald S. Pady, The Medico-Psychological Interests of King James I; Nathaniel Laor, Hobbesian principles in Szasz's writings; G.A. Lindeboom, Geschichtliche Meilensteine in der Behandlung der Nachtblindheit; Georgette Delpech, Histoire des Plaquettes sanguines: des 'molécules' à la 'cellule'; Eduard Wondrak, Leopold Berchtold (1759-1809) und die Anfänge der Berufshygiene und Unfallverhütung; Francis Schiller, An eighteenth century view of the Placebo effect (Rétif de la Bretonne); Fred Rosner, The Ordeal of the Wayward Woman (Sotah): Miracle or Natural Phenomenon; Fridolf Kudlien, Keuschheit und Heilkraft, Sander L. Gilman, Hottentotten und Prostituierte: Zu einer Ikonographie der Sexualisierten Frau; Andre de Vries, The enigma of Darwin; Lars H. Breimer, Did Moriz Kaposi describe AIDS in 1872?; Essay Review; Book Reviews; Books Received.

\section{DEUTSCH-NIEDERLÄNDISCHE \\ BEZIEHUNGEN IN DER MEDIZIN \\ DES 18.JAHRHUNDERTS. Vorträge \\ des Deutsch-Niederländischen \\ Medizinhistorikertreffens 1982}

herausgegeben von R. Toellner und M.J. van Lieburg

Amsterdam 1985. 92 pp. (Nieuwe Nederlandse Bijdragen tot de Geschiedenis der Geneeskunde en der Natuurwetenschappen. Nr. 14). ISBN: 90-6203797-6

Hก. $25,-$

Inhalt: J. Geyer-Kordesch, 'Der Galante Patient': Verhaltenserwartungen für Kranke im 18. Jahrhundert in Deutschland; H.L. Houtzager, Van Leeuwenhoek, Leibniz und der Animalkulismus; G.A. Lindeboom, Boerhaave's Einfluss in den deutschen Staaten; G.A. Lindeboom, Historisches zum Begriff 'Enzyklopädie' -Die Wissenschaftskunde von Johann Joachim Eschenburg (1743-1820); D. de Moulin, Lorenz Heister (1683-1758), Vermittler zwischen der deutschen und niederländischen Chirurgie; E. Petterson, Medizinische Darstellungen in der niederländischen Malerei des 17. Jahrhunderts; H.A.M. Snelders, Die Reaktion des Amsterdamer Pharmazeuten Kasteleyn auf die Auffassungen der Erlanger Arztes Hildebrandt bezüglich des Phlogistons. Ein Beitrag zur Geschichte des Phlogistons;

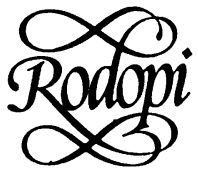

Keizersgracht 302-304

1016 EX AMSTERDAM-HOLLAND 


\section{MEDICAL BOOKS}

\section{Prints * Portraits}

\author{
OLD, RARE,
}

\section{\& OUT-OF-Print}

\section{America's Largest Stock}

All items are fully catalogued and classified. American and European, dating from the 15th to the 20th centuries particularly classical and unusual works. with emphasis upon history, biography, and specialized medicine.

Lists issued in all fields of medicine.

We are eager to purchase small or large collections.

\section{ARGOSY BOOK STORES}

116 E. 59th St., N.Y., N.Y. 10022. PL.3-4455

Rare Books \& Manuscripts in the bistory of

\section{Medicine \& the Sciences}

BOUGHT · SOLD · APPRAISED

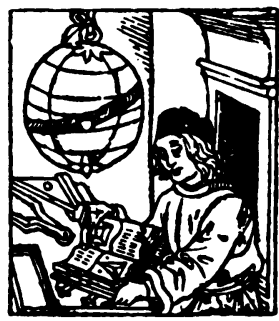

Send for our latest catalogue Jeremy Norman \& Co., Inc.

$$
442 \text { POST STREET }
$$

SAN FRANCISCO, CALIFORNIA $9+102$

$$
\text { (415) } 781-6402
$$

F.E.

Whitehart

40 Priestfield Rd.

Forest Hill

London SE23 2RS

01-699 3225
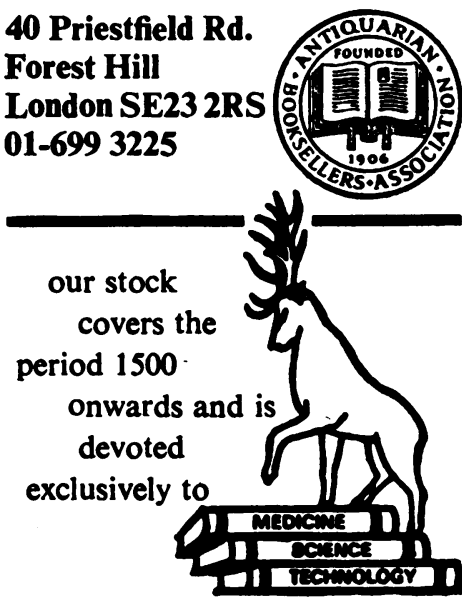

CATALOGUES ISSUED

Normal business hours or by appointment

Antiquarian books in the history of medicine and the health sciences.

Please send for my catalogue.

\section{RADCLIFFE SQUARE PUTNEY HILL LONDON SW15 6BL ENGLAND}

Tel: 01-788 2664 